\title{
Pengetahuan terhadap bahasa kebangsaan sebagai teras pembinaan peradaban Malaysia dalam kalangan mahasiswa di Lembah Klang
}

\begin{abstract}
ABSTRAK
Makalah ini bertujuan membincangkan tahap pengetahuan bahasa kebangsaan dalam kalangan mahasiswa di institusi pengajian tinggi (awam dan swasta) dari aspek i) sejarah, ii) dasar dan iii) kedudukan bahasa Melayu di dunia. Sehubungan itu, satu kajian telah dijalankan di Universiti Malaya, Universiti Kebangsaan Malaysia, Universiti Multimedia dan Unisel, Selangor.Seramai 460 orang responden diperoleh melalui kaedah pensampelan rawak berstrata. Data dikumpul menggunakan borang soal selidik dan dianalisis secara deskriptif. Hasil dapatan menunjukkan majoriti mahasiswaIPT mempunyai pengetahuan yangtinggi terhadap semua dimensi, iaitu sejarah, dasar dan kedudukan bahasa Melayu di dunia. Namun, terdapat beberapa item dalam dimensi dasar dan kedudukan bahasa Melayu yang menunjukkan pengetahuan yang rendah. Justeru, pengetahuan mengenai dasar bahasa kebangsaan dan kedudukan bahasa Melayu di dunia perlu dipertingkatkan melalui media massa atau dalam proses pengajaran dan pembelajaran agar mahasiswa dapat lebih menghayati Perkara 152 Perlembagaan Malaysia mengenai bahasa Melayu sebagai bahasa kebangsaan yang menjadi teras kepada perpaduan seterusnya tamadun Malaysia.
\end{abstract}

Kata kunci: Tamadun; Pengetahuan; Bahasa kebangsaan; Mahasiswa 